\title{
DIMENSIONS OF CRIME INVOLVING WOMEN IN DRUG TRAFFICKING - LITERATURE REVIEW FROM DEPENDENT BEHAVIOR TO RELAPSE
}

\author{
DOI: http://doi.org/10.26758/11.1.7
}

Miana DINA (1), Jose Manuel Rodriguez GOMEZ (2), Cornelia RADA (3)

All authors of article have contributed equally.

(1) PhD. Student, School of Advanced Studies of the Romanian Academy, "Constantin RădulescuMotru" Institute of Philosophy and Psychology, Department of Psychology, Romanian Academy, Bucharest, Romania;

(2) Guardia Civil de Madrid, Ministerio Del Interior, Espania, e-mail: pinodeloro@ hotmail.com;

(3)"Francisc I. Rainer" Anthropology Institute of the Romanian Academy, e-mail: corneliarada@yahoo.com

Address correspondence to: Miana Dina, National Administration of Penitentiaries, Directorate of Social Reintegration, Maria Ghiculeasa, No.47, 2th Distinct, Bucharest, 023761, Romania. Ph.:+40021- 27583; Fax: +40-021-242.05.05; E-mail: grebenar.miana@ yahoo.com

\begin{abstract}
Objectives. The aim of this study was to review the most important factors influencing women's involvement in drug trafficking.

Material and methods. A systematic search of literature was carried out using Web of Science, Academic Search Complete, ProQuest Central, PsychInfo. The inclusion criteria were met by fiftytwo studies. In order to facilitate the understanding of the behaviour of women who commit this crime, factor analysis was grouped into social-cultural, personal and psychological factors.

Results. The main social and cultural factors considered were the adopted political system, the racial element, the cultural-regional peculiarities, the geographical positioning, the socio-economic status and the sociofamilial environment. The personal factors identified were age, occupation, lifestyle, system of norms and values, and psychological ones referred to indicators of psychological disorders, addictive behavior, the ability to control reactions and the perceived level of self-efficacy.

Conclusions. The factors with the highest share of drug trafficking among women were group membership, economic and social status, educational level of parents and friends, prison history and drug use. If in the rural area the main factor that determines women to get involved in drug trafficking is the lack of a job and a low level of education, in the urban area, the influence of the group is significant. Regarding the reasons behind the involvement of women in such criminal acts or in the manifestation of addictive behaviors, these are often compensatory mechanisms, adopted in the absence of effective coping strategies.
\end{abstract}

Keywords: women, drugs, trafficking, addiction, relapse.

\section{Introduction}

Although the global increase in female drug trafficking has highlighted the need to identify determinants, a limited number of researches have been carried out on this issue over time (Faupel, 2010; Ritchie, 2017). Also, in scientific debates and studies, the link between drug use and trafficking in women was one of the less observed and debated topics (Faupel, 1987).

Since specialists in the field have observed that, despite the experience of incarceration, a large proportion of women continue to use drugs and carry out trafficking even after being released 
from prison, the importance of the psychological dimensions that can influence this type of behavior have been pointed out (Kensy, Stengal, Nougier, \& Birgin, 2012). According to Bergman (2018) it is the presence of an addictive behavior, namely the use of illegal substances with an onset prior to the involvement in drug trafficking, not only facilitated the commission of the criminal act but also the state of relapse.

In terms of global consumption, in Europe it is estimated that more than 92 million people aged 15 to 64 years (which represents more than $25 \%$ of the Union's population) have tried illegal drugs at some point in their lives. In Germany, approximately 3.7 million of the population reported frequent cannabis use (Atzendorf, Rauschert, Seitz, Lochhühler, \& Kraus, 2019), and in Italy, "in 2009-2016, there was an increase in the number of people using drugs, $20 \%$ confirming the use of more than one drug, $18 \%$ for cannabis and cocaine, $6 \%$ for benzodiazepines and $3.5 \%$ for methadone" (Carfora, Campobasso, Cassandro, Petrella, \& Borriello, 2018).

In southern Europe, drug use is constantly increasing, in Portugal, about $35 \%$ of the population reported drug use, ethanol being the most commonly identified psychoactive substance, i.e. in 55\% of cases, between January 1990 and December 2007 (Costa et al., 2012). At the same time in Spain, between 2003 and 2016, 10\% of the population reported cannabis use, and in Bulgaria 3.5\% of cases supported this fact (Montanari, Guarita, Mounteney, Zipfel, \& Simon, 2017).

In northern Europe, according to researchers Buvik, Bye and Gripenberg (2019), Nordic countries differentiate themselves from others by a much lower rate of consumption. In Sweden, drug use varies by age and region. Cannabis use was more common in southern Sweden than in the northern region. At the same time, high alcohol consumption and illegal drug use appear to be more widespread in those parts of Sweden that are closer to the European continent (Bränström \& Andrésson, 2008).

In Romania, as reported by the study conducted in 2019 by the National Anti-Drug Agency (ANA) "compared to the European average, lifetime use (at least once in a lifetime) is lower for all categories of illicit drugs analysed. The most widely used illicit drug among adolescents continues to be cannabis/hashish, followed by new psychoactive substances (NPS)". The study shows that "there is a better perception of the risks of experimental use of new psychoactive substances, amphetamines and ecstasy, with an increasing proportion of those who attribute high risks to such consumption. The greatest risks are for amphetamine use and cannabis use" (ANA, 2019).

In the USA, after 2012, heroine and cocaine use was frequently associated with a considerable mortality rate (Walker, Pratt, Schoenborn, \& Druss, 2017) and in Australia "after the year 2000, the prevalence of drugs (other than alcohol) was present in $26.7 \%$ of cases, and psychotropic drugs in $23.5 \%$, namely cannabis (13.5\%), opioids (4.9\%), stimulants (4.1\%), benzodiazepines (4.1\%) and other psychotropic drugs (2.7\%)" (Drummer et al., 2003).

Even in states where the political system is characterised by a high level of control over the population, the phenomenon of drug use and trafficking has seen a considerable increase. In Russia, according to the study conducted by Kartashev and his collaborators (2016) between 2011 and 2015, drug use and trafficking has increased considerably, with $23.8 \%$ of drug trafficking committed by organised groups, and in Jordan, between 2008 and 2014, 36.5\% of cases confirmed psychotropic drug use, with users aged between 19 to 29 (Al-Abdallat et al., 2016).

Given that more than $70 \%$ of illegal drug use is used at retail level, in those states that have become strategic regions for the international drug market (Belgium, Spain, the Netherlands), women can hold important roles (Bergman, 2018).

The idea has emerged that women involved in the drug world belong to the category of "specialist criminals". They are qualified in at least one or two offences, which they rely on to produce their own income. Sometimes committing a single offence cannot provide the desired financial support, and therefore the achievement of at least two offences increases this possibility. Such specialisation involves learning important skills that facilitate not only the commission of the crime but also ways of detecting and avoiding arrest (James, Gosho, \& Wohl, 1979). 
In view of the above circumstances, it is useful to carry out a systematic search of the literature in order to identify the factors that motivate women to engage in drug trafficking, both locally and internationally.

\section{Material and methods}

\section{Purpose and Objectives}

The purpose of this study was to explore existing research on the topic of determinants in drug trafficking in women. Thus, the objective of this study was to highlight the main social-cultural, personal, but also psychological factors encountered in the commission of this criminal act.

The analysis of the specialized studies and their results focused on the following research questions:

1. What social-cultural factors are involved in drug trafficking in women?

2. What personal factors are found in the choice to commit this crime?

3. What are the psychological factors that cause women to commit drug trafficking?

\section{Search strategy}

A systematic search of the literature was carried out and the following databases were used: THOMSON ISI - Web of Science, EBSCO - Academic Search Complete, ProQuest Central, PsychInfo, but also numerous manual searches via Google Academic Search Engine. Among the main journals identified are The Journal of Ethnicity in Substance Abuse, Drugs \& Society, International Feminist Journal of Politics, Journal of Criminal Justice Education, Journal of Crime and Justice.

The search covered the period from 1979 to August 2020.

Two types of variable categories were used, namely, demographic variables that included the gender - female and age category - at least 14 years, as well as psychological, aspects of vulnerability, respectively.

As far as the psychological picture is concerned, the main vulnerable dimensions that facilitate both involvement in such crimes and the perpetuation of such behaviour have been analysed. The target was to identify the main determinant factors, to understand what motivated the appearance of women in the drug market, but also to outline a complex picture of women drug dealers.

\section{Selection of studies}

The first author independently selected the studies with iligible potential according to the search criteria. In the first phase, the selection was based on title and summary, and in the second phase on the full-text article. All studies identified during the first selection phase were re-evaluated in the second selection phase. The inclusion criteria consisted in the age category - participants to be at least 14 years old, gender - to be female and to refer to psychological characteristics whose form of expression may have significant consequences in terms of the manifestation of behavior according to the socio-cultural norms.

The following keywords were used: trafficking, drugs, women, addiction and relapse. For each keyword a certain number of studies were explored, namely women $=$ seven studies, drugs $=21$ (twenty-one) studies, trafficking $=$ seven studies, dependence $=$ six studies, relapse $=11$ (eleven) studies. The selection process of the studies is summarised in Figure 1. 


\section{Figure 1}

The selection process of the studies included in the article

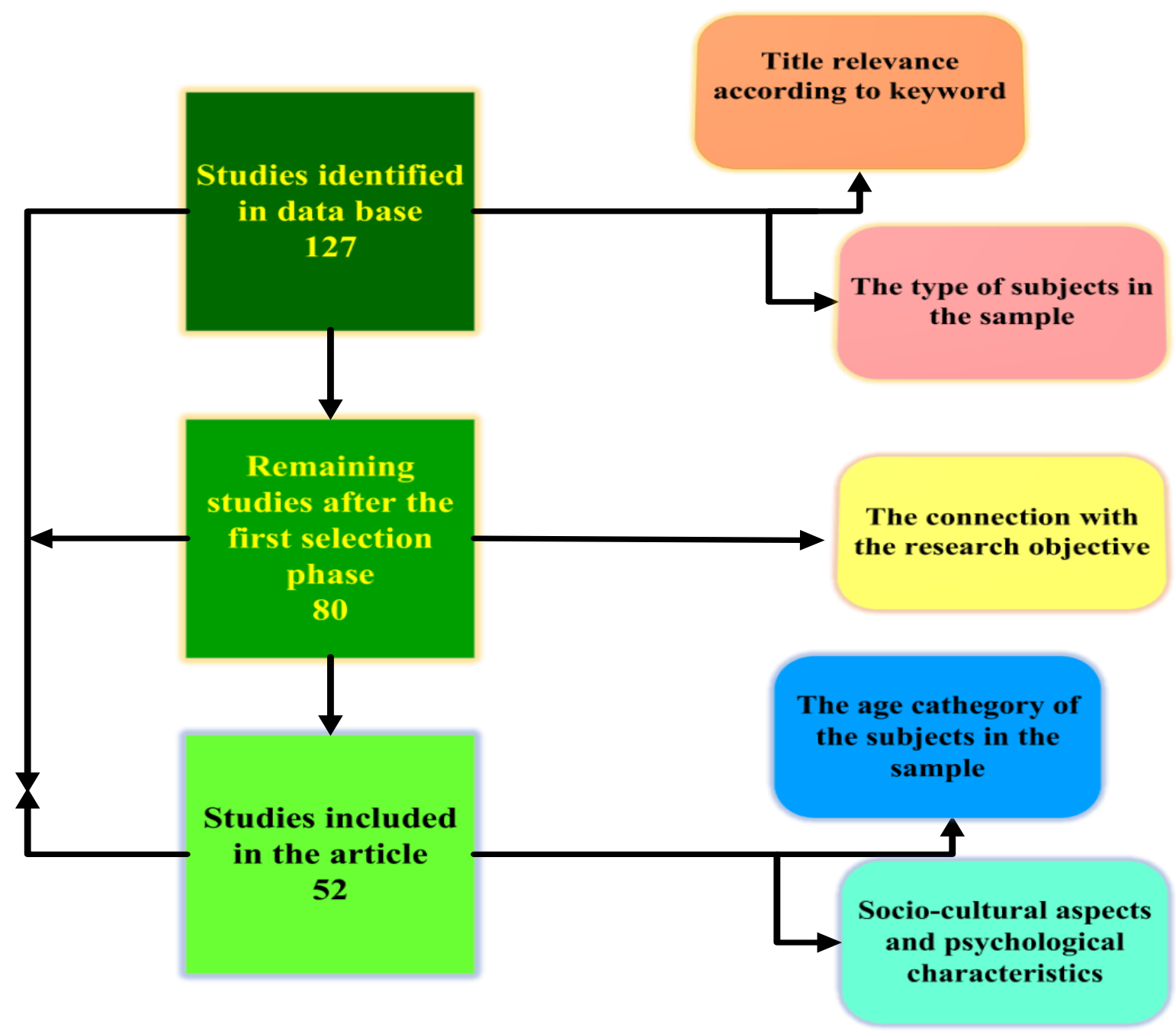

\section{Data extraction}

Data extraction and evaluation of the quality of studies were carried out by the first author and independently verified by the third author. Disagreements were resolved by consensus. Data on the target group, the presence of information to support the information, as well as recruitment methods were highlighted (the main condition was expressed voluntary agreement).

The methodological quality of the studies included was assessed according to the following criteria: sample size, adequacy of randomization and management of missing data.

The quality of one study was assessed as high when all three criteria were met, an average when only two criteria were met and low when only one was met. 10 (ten) low-level studies, 21 (twenty-one) of average quality and 21 (twenty-one) high-quality studies (Figure 2) were evaluated. 


\section{Figure 2}

The evaluation process of the studies included in the article

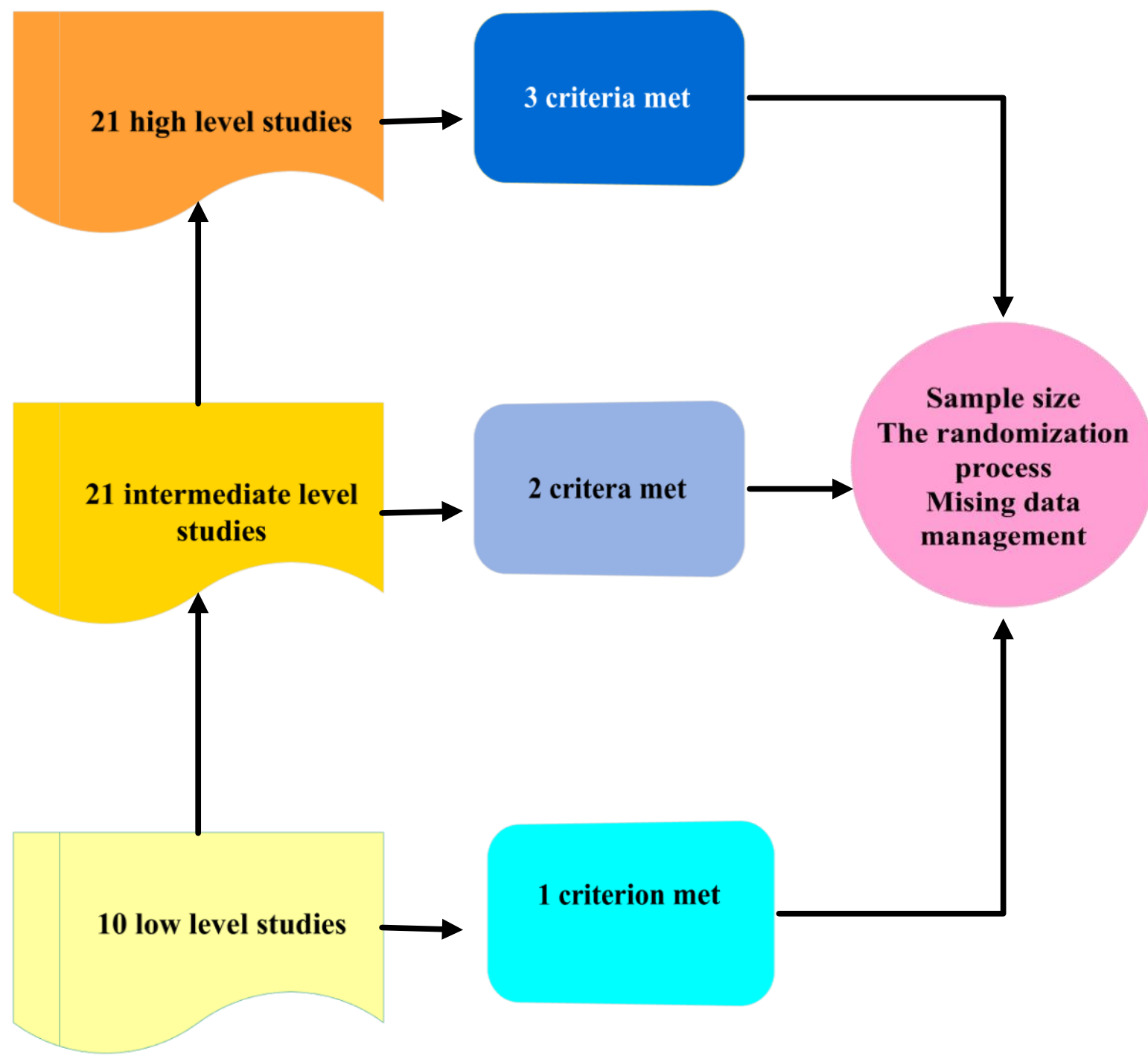

Tables 1, 2, 3, 4 and 5, located after the Study limitations section, show the adjacent studies and conclusions for each keyword used in this article. Information regarding author(s), year of publication, place of study, type and size of the sample were retained.

\section{Results}

The following social-cultural factors responsible for women's involvement in drug trafficking were identified in 24 studies: the political system adopted (criminal justice); racial discrimination; geographical positioning, cultural-regional peculiarities (promotion of nightlife); socio-economic status (poverty); socio-familial environment (reference group, identity incongruity, number of children, absence of roles and responsibilities, educational level of the family) (Figure 3). 


\section{Figure 3}

Social-cultural factors involved in the case of women who have committed drug trafficking

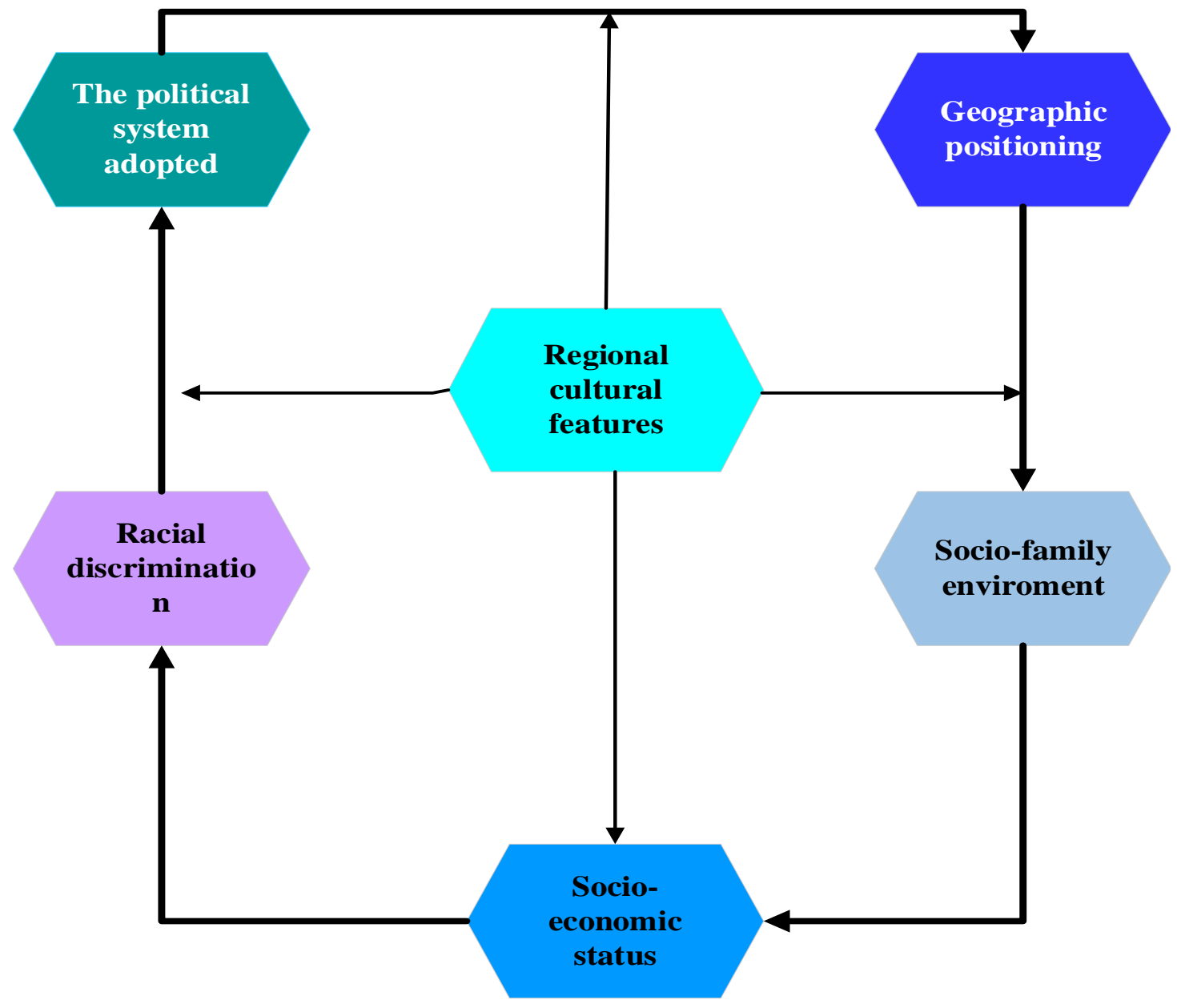

The personal factors of women who committed drug trafficking were analyzed in 10 studies. These are: lifestyle (carceral history, risk behaviours, prostitution, drinking and driving); personal values (disregard for the rights of others, lack of morality); age (adolescence); occupation (joining criminal groups, organised crime, human trafficking and money laundering) (Figure 4). 


\section{Figure 4}

Personal factors involved in the case of women who have committed drug trafficking

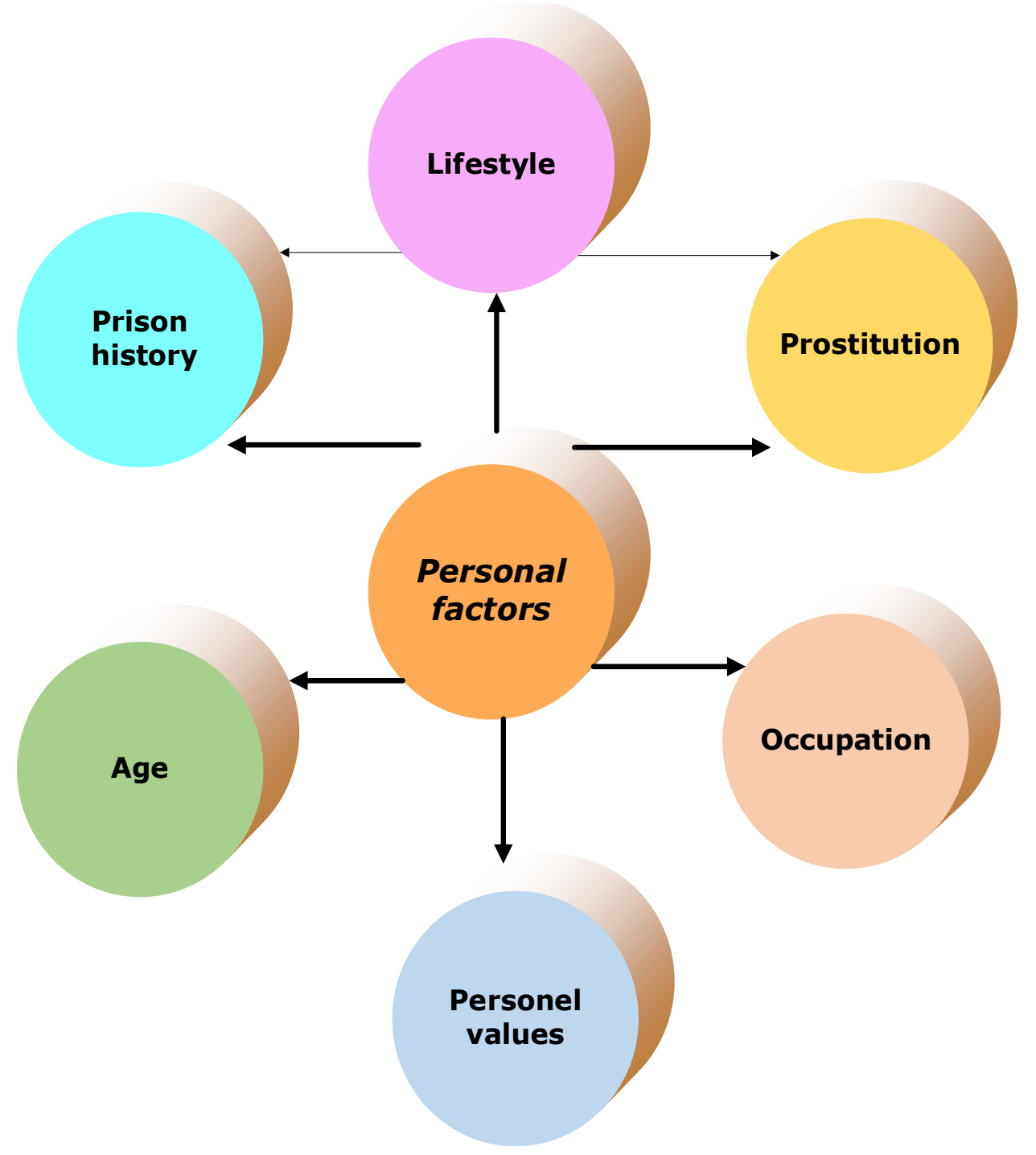

The following psychological factors of women involved in drug trafficking in women were identified in 18 studies: indicators of psychological disorders (depressive mood, suicidal ideation, anxiety, emotional lability, emotional and behavioral imbalance); perceived level of self-efficacy (self-esteem, confidence in one's own problem-solving skills); ability to control one's own reactions (disguise, self-control); addictive behaviour (drug use, adrenaline and ecstasy) (Figure 5). 


\section{Figure 5}

Psychological factors involved in women who have committed drug trafficking

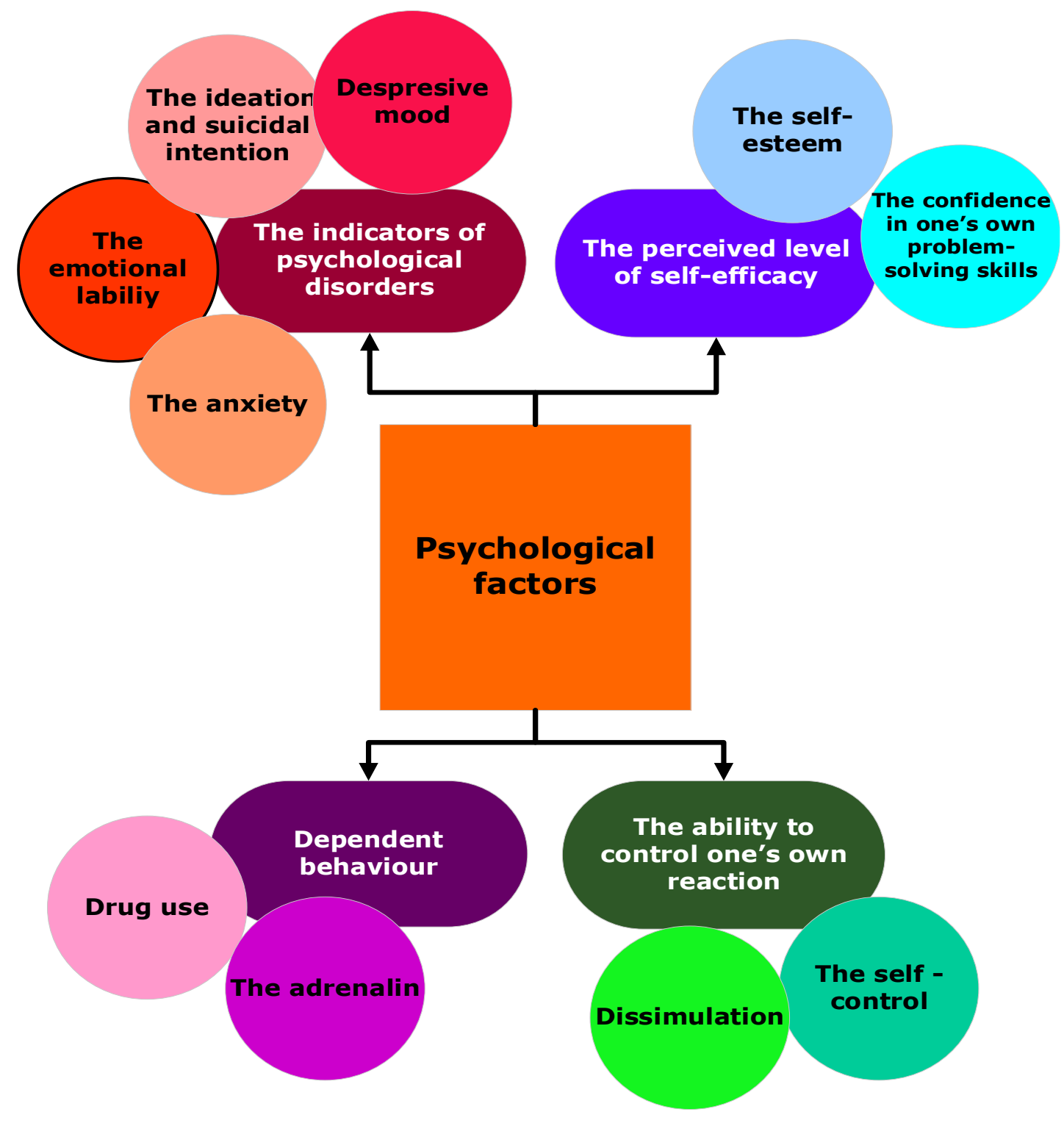

\section{Discussions}

\section{Social-cultural factors}

Although the war on drugs in the US was declared as early as 1971 by President Richard Nixon, attention to crime in women returned after a period of pause, i.e. after the 1980s, when the literature began to look again with interest on the involvement of women in drug trafficking. According to Fondevila, Massa and Meneses-Reyes (2020) researchers in the 21st century, there has been a higher incarceration rate in the United States than in any other country, but with immediate effects on the minority population. As per to the three authors, between 1986 and 1995, the arrest of adult women for drug abuse violations increased by "91.1\% compared to $53.8 \%$ for men, and from 2010 to 2014 , women's arrests increased by $9 \%$, while for men they decreased by $7.5 \% "$.

Despite the fact that this fight against drugs concerned the distribution and use of drugs, the particular effects for women occurred in the form of their criminalisation and selective incarceration. 
According to Johnson and Young (2002) this increased selectivity is found mainly in African women. Following a qualitative study of five incarcerated African women, former drug users and drug traffickers, the analysis revealed that they were in financial difficulties and did not receive support in this regard. As a result of this situation, women were stigmatized in several ways, including sexual abuse, drug use, and drug trafficking. At the same time, conforming to Schemenauer (2012) and Moloney, Hunt and Joe-Laidler (2015) most often female couriers are described as victims of a racial subculture, Madonnas that carries out drug trafficking in order to benefit from some male protection.

As can be seen, an important role in criminal justice policies is gender bias, social class and discriminatory race-based elements (Nicewarner, 2019). Considered to be partially effective, several authors consider that in many cases of drug use and trafficking, the restorative justice policies can be more appropriate ways, as they include simultaneous interventions for both the offender and the victim (Dandnord \& Griffiths, 2006; Dignan, 2005; Van Ness, Morris \& Maxwell, 2001; Braithwaite, 2002). In fact, in agreement with Oancea and Micle (2015) law enforcement is "a process of social influence", and for an effective rehabilitation program, careful focus is needed, both on dealing with antisocial attitudes and on cognitive development, designed to help them solve problems.

Another phenomenon that has led to the emergence of women in the USA on the drug market and in criminal activity is the absence of the probation system in regions at risk of criminal acts (Robbins, Martin, \& Surratt, 2009). The mere incarceration of a person from a disadvantaged area and the lack of focus on programs to provide support in obtaining financial resources has to some extent led to a continuity of women's involvement in drug trafficking (Olson, Stalans, \& Escobar, 2016).

In Europe, the phenomenon of drug trafficking has focused more on state interests, "from the individual policies of the liberal Netherlands to Sweden's repressive policies" (Chatwin, 2003). In consonance with Chatwin (2016) across Europe, there are no common indicators of success that allow drug policies to be judged, the cultural peculiarities having their say depending on each region. If in Italy drug trafficking is primarily influenced by the existence of specific routes, social and geographical proximity being key factors that explain the configuration of heroin supply (Giommoni, Aziani, \& Berlusconi, 2017), in the UK, drug trafficking is facilitated by the particularity of leisure spaces, such as cafes, dance clubs, those spaces that offer pleasure for the consumer society, and can represent an opportunity in the conduct of drug-related crimes (Measham, 2004). Also, in Romania as reported by Baciu's qualitative study (2018) attended by 30 students from the Faculty of Medicine in Bucharest, aged 20-21 years, it seems that the students considered that the places where illegal drugs could be used are the most withdrawn, unlit, as safe from other people as possible, at parties, in clubs or in parks and parking lots, at night.

Nor should the strategic role given by the geographical positioning of these states be omitted. For example, Romania fulfils the role of "transit country", facilitating the involvement of women in drug trafficking. The emergence of new routes for heroin trafficking to intermediate destinations such as Georgia requires a growing diversification of criminal groups in order to achieve their objective. Concealing criminal infrastructure with commercial activities that avoid possible risks, ensures a major role for women in this regard (Nucu, 2018).

According to the Direction of Investigation of Organized Crime and Terrorism Crimes [DIICOT], Romania has become a "target country" of risk drugs, especially in the case of cannabis, and in recent times the number of cases of illicit cannabis plantsh has also increased. Even in this situation, women can play a key role. Given that the prevalence of women in the countryside is higher than men, but also that obtaining financial income is more difficult for women than for men, in this context of physical work, involvement in such activities is perceived by them as a solution. If in rural areas the lack of jobs causes women to commit drug trafficking, in major cities they are influenced rather by the group of friends and the ways of promoting nightlife (Tical, 2019).

Another factor is the influence of the reference group and the entourage. The results of a study of 500 participants in Saudi Arabia showed that the predictor with the highest share in substance 
use and trafficking is the influence of the membership group (Beaver et al., 2016). Similarly, in Italy, the results of a study of 33,185 adolescents between the ages of 15 and 19 highlighted the influence of the membership group in terms of drug use and trafficking, as well as the high educational level or, on the contrary, of parents and friends (Denoth, Siciliano, Iozzo, Fortunato, \& Molinaro, 2011). As per to Stanciu and Cotruş (2014) it seems that young people whose parents have a lower social status and have no resources, or who have parents of high status, are more inclined to drug consumption, due to lack of supervision and with a considerable financial support, create this opportunity for the world of drugs.

At the same time, in Romania the results of a quantitative study, carried out in the period 2017-2018 on a sample of 459 students and students showed that the example offered by friends influenced the behavior of adolescents and young people more than that offered by the family, most of them using drugs under the influence of friends or at their urging, to "be of their own", "to be cool", "to see what it is like to smoke cannabis" (Baciu, 2019).

The influence of one's background can determine the degree of involvement in such activities. The existence of models in the family, the lack of responsibilities or of children, influence the commission of crime by adopting behaviors against social norms (Fowler, Dinitto, \& Webb, 2005). A qualitative study from New Zealand highlights that women who do not have children and use drugs tend to commit more serious crimes, i.e. to carry out drug trafficking in more dangerous conditions or in greater quantities. This non-existence of a possible affective bond, which could have been given by motherhood, increases the probability of manifesting risky behaviors (Hutton, 2005).

\section{Personal factors}

US specialists said that the lifestyle and implicit social norms by which a person is guided are key elements in the commission of such a crime (Flynn \& Hoffer, 2019; Bergseth, Jens, BergeronVigesaa, \& McDonald, 2011; Dodge \& Pogrebin, 2001). Thus, involvement in criminal activities and criminal history can be significant factors in shaping this lifestyle for women who consume and carry out drug trafficking (Bui \& Morash, 2010). In their study of the needs of incarcerated women, consisting of 402 women who committed crimes, Holtfreter and Morash (2003) highlighted the implications of custodial sentences, notably the lack of community programs and services that can provide specialized assistance for the purpose of lowering the relapse rate and for adopting a different lifestyle.

At the same time, the presence of risk behaviours is part of this lifestyle, Jørgenrud et al. (2018) stating in a study of 5031 male and female participants, from Norway, between April 2016 and April 2017, that speeding and drink driving use are found in drug traffickers. Alantes, Fraile and Page (2002) also argue that the occurrence of such risky behaviour is often found in women who are involved in drug crime.

Similarly, Calafat et al. (2009) in his study of 1363 participants in nine European cities concluded that in their case, the most common risk behaviour linked to drug trafficking turns out to be prostitution.

Other authors (Hughes, Chalmers, \& Klimoski, 2018) suggested through a systematic analysis carried out in Australia, in two distinct periods, namely 2005-2006 and 2014-2015, that drug trafficking is most likely linked to money laundering, fraud, corruption and human trafficking. Therefore, the main occupation of people who commit drug trafficking is organised crime.

Bellis and his colleagues (2008) through a study of 1,314 participants aged 16 to 35 from nine European cities point out that drug trafficking occurs more in teenage girls, but who are also involved in other criminal activities. It also seems that in large cities where the concept of freedom is lived at intense levels, drug use and trafficking is closely related to the states of excitation or ecstasy in sexual intercourse. As a result, girls under the age of 16 who were engaged in cocaine use and trafficking were five times more likely to have had more sexual partners in the past 12 months. 


\section{Psychological factors}

Psychological disorders, i.e. personality disorders or anxiety disorders are often found in women involved in such criminal activities. In line with several authors (Wexler, Cuadrado, \& Stevens, 1998; Stevens, Andrade, \& Ruiz, 2009) there appears to be a direct relationship between the addictive behavior, the seriousness of the crime committed and the presence of several signs of psychological disorders. At the same time, Brownstein, Baxi, Goldstein and Ryan (1992) using data from 414 homicide cases in New York, highlighted the association of depression with constant drug use or overdose against a background of emotional instability.

Although depressive symptoms were correlated with people who were trafficking drugs for the purpose of obtaining money for personal use, Iwamoto, Liu and McCoy (2011) in their study of 163 Asian women, they did not identify correlations between drug trafficking and coping strategies. In fact, the manifestation of dependent behaviours often constitutes compensatory mechanisms in the absence of effective coping strategies. In-depth interviews of several incarcerated women allowed an understanding of the evolution from victim to survivor and then to the offender. Women who have been subjected to different forms of abuse are subject to these compensatory mechanisms, such as drug use and trafficking (Gilfus, 1993).

Emotional liability, emotional and behavioral imbalance are also psychological characteristics found in women with a history of drug use and trafficking, Murphy, Stevens, McGrath, Wexler and Reardon (1998), concluding these aspects in their study of 98 women enrolled in a residential drug treatment center in Tucson, Arizona.

This spectrum also includes low self-esteem, how the person perceives himself as image and self-confidence, feelings of shame and submissive behavior. As per to studies by Haselschwerdt, Maddox and Hlavaty (2020) on 23 women in California, as well as studies by Radosh (2008), these are psychological dimensions found in women convicted of illicit drug use and trafficking. According to Micle and his colleagues (2013) it is self-esteem that sustains the person in those difficult situations in life, and a person with negative self-esteem will tend towards states of unhappiness and anxiety.

Another register lists the conclusions of Marsh's qualitative study (2016) on a sample of 16 women from Ecuador who participated in international drug trafficking, which highlighted the existence of a high level of self-control, concealment as well as good problem-solving skills. The same aspects were discovered in studies conducted by Dotherte, Jacinto, Sales, \& Murphy (2009) on a sample of 80 drug dealers in California, but also by Ludwick, Murphy and Sales (2015) on a sample of 160 drug dealers in the San Francisco Bay Area.

Grace (2017) concludes that in the UK, another factor involved in drug trafficking is drug use itself. Women use drugs not only for pleasure, but also to cope with difficult life circumstances, such as domestic abuse, and addictive behaviour thus becoming a compensatory measure in the absence of effective coping strategies.

And in Spain, drug use is very common among women incarcerated for drug trafficking. Sánchez, Fearn and Vaughn (2018) said in a research that examined the prevalence and correlations of drug use in the penitentiary, on a random sample in four regions of Spain, that the previous history of drug use was significantly associated with substance use in prison, with trafficking women more prone to addictive behaviour.

In view of the international report on the drug situation in Europe and the rate of use as well as the market, by "age group 15-34 years, the prevalence of drug use ranges from $0.4 \%$ in Turkey to $22.1 \%$ in France for cannabis, from $0.2 \%$ in Greece and Romania to $4.2 \%$ in the United Kingdom for cocaine, and from $0.1 \%$ or less in Romania, Italy and Portugal at $2.5 \%$ in Estonia for amphetamine". According to the researchers, drug trafficking is closely linked to drug use, so dependent women are more inclined to practice drug trafficking (Mounteney et al., 2016).

Also, in Romania, drug trafficking is closely linked to drug use, with dependent women more likely to commit this crime (Stanciu \& Cotruş, 2014). 
The Australian Institute of Forensics draws attention to important differences in drug use patterns in women compared to men. Thus, the risk factors for drug use differ significantly, depending on both the experienced history and the perception of the phenomena in each person's life. If in the case of women a leading role is represented by a history of traumatic potential, namely sexual and physical abuse, as well as early exposure to dependent behaviour in the family environment, in the case of men, the perception of the surrounding world, influenced by the entourage and the need to affirm masculinity, is an essential element. Understanding this connection between the underlying variables of drug use can help develop interventions and crime reduction strategies for female offenders (Taylor, 2015).

In view of the above, in order for addicts to be perceived as people who have a serious problem, and not as a "chaff" of society, with no chance of recovery, it is important not only to increase the level of education but also to inform society about drug use (Baciu, 2017).

\section{Conclusions}

This study aims to identify the main factors underlying women's involvement in drug trafficking, as well as to highlight their psychological characteristics, with the aim of shaping ways to stop this phenomenon.

Regarding the first question of this study - What social-cultural factors are involved in drug trafficking in women? it can be observed that the social-cultural factors that have an impact on women's involvement in drug trafficking are the political system adopted, discrimination on the basis of race, the cultural peculiarities of each region, geographical positioning, socio-economic status, but also the socio-family environment.

Society's focus on criminal and less on restorative policies has facilitated the imprisonment of women who have committed drug trafficking but could not control the criminal repression. Although this type of policy ensures that potential sources of crime are reduced, full control is not possible, nor can we speak of eradicating the criminal phenomenon.

If in the United States of America discrimination based on race (black population) facilitated this measure, in the case of Europe the cultural peculiarities and the perception of the concept of freedom led women to a large extent to commit this type of crime.

In northern Europe, where the educational level is higher, drug trafficking is much lower, and in the southern part of Europe the incidence of drug trafficking in women is much higher. At the same time, if in the rural area the main factor that causes women to get involved in drug trafficking is the lack of employment and a low educational level, in the urban area, the influence of the membership group is significant.

It is obvious that, not only the educational level of the person concerned, influences this behaviour, but also of the family, in this case of the parents. Thus, whether it is a high level, which causes parents to be more concerned with professional activity, at the expense of spending time with their own child and careful monitoring him, or it is a low level, which reduces the chances of providing an appropriate family model for the development of prosocial values.

At the same time, the absence of roles and statuses, the absence of children or responsibilities, emphasizes this perception of freedom taken to the extreme, the idea of living the moment, regardless of the consequences, becoming a priority in this type of situation. Freedom, led to the extreme by disregarding moral principles, leads women to follow different models in the membership group and to engage in such illegal acts.

As well, the influence of large cities and nightlife facilitates both trafficking and drug use. The existence of a space that can represent an opportunity for drug use leads to the emergence of drug trafficking. In Romania, the influence of the sociofamilial environment, the lack of studies or the existence of jobs in the vicinity of the home, leads women to get involved in this type of criminal acts, allowing them to obtain financial income. 
Regarding the second question of the study - What personal factors are found in the choice to commit this crime? the studies analysed have shown that age, occupation, lifestyle and therefore personal values are the main personal factors found in women involved in drug trafficking. Lifestyle characterized by the manifestation of risk behaviours such as drunk driving, prostitution, the commission of criminal acts in a repeated manner and therefore the existence of the criminal history, support this involvement of women in drug trafficking.

Since lifestyle is the strategic option adopted by a person, the activities to which he or she will decide to turn will be those that will guide decisions, behaviours and living conditions. In this context, the appropriation of a system of anti-social values, such as disregard for the rights of others and lack of morality, is nothing more than a tribute to the beliefs and representations he or she has formed about the world and life, and by virtue of which he or she chooses, behaves and acts. The decision to be part of criminal groups, especially those that commit human trafficking and money laundering, is part of this lifestyle, based on occupations against the legal system, but which constitute financial sources of living.

In the case of young women, especially in the case of teenage girls, the group of friends, and the entourage are elements that influence this value system. The need to be accepted, to be like others or to be the center of attention, causes them to enter a vicious circle, in which drug trafficking correlates with drug use. Therefore, the younger women are, the greater their likelihood of drug trafficking.

The third question - What are the psychological factors that cause women to commit drug trafficking? refers to indicators of psychological disorders, perceived level of self-efficacy, ability to control their own reactions, but also to addictive behavior. The presence of signs of psychological disorders such as depressive mood, suicidal ideation, anxiety, emotional lability, emotional and behavioural imbalance can often be psychological factors that facilitate women's involvement in drug trafficking.

Negative self-assessment of one's own chances of success, failure to accept weaknesses and flaws, and severe self-criticism are the basis of a lack of balance. At the same time, feelings of guilt, fear or negative beliefs about oneself contribute to a generalized state of anxiety and dependent personality structure.

High levels of stress and a state of emotional vulnerability can lead to depressive states, negative emotional states, as well as involvement in different risk behaviors. These include drug abuse. A woman addicted to drugs may be at high risk in terms of involvement in drug trafficking, as there is a certainty that she will be able to benefit from the physical element that ensures pleasure and determines the momentary well-being, namely the drug.

The absence of coping strategies, poor concealment capacity and low level of self-control lead these women, in certain situations, to adopt drug trafficking as a compensatory mechanism. Although this psychological vulnerability is very common in women who traffic drugs, the category of women demonstrating outstanding skills in the coordination of these crimes should not be omitted.

On the one hand, women who commit drug trafficking, can belong to the category of those who do not trust themselves, are easily influenced, have a poor ability to adapt to new situations and are hesitant in their behaviour, and on the other hand there is the category of those who lack empathy, guide their behaviour according to their financial objective, tend to overestimate their capabilities, disregard moral values and have good problem-solving skills. 


\section{General conclusions}

In order to be able to stop this phenomenon, it is necessary first of all to apply measures to raise awareness at the level of society, the consequences and risks that drugs have. Media prevention campaigns, but especially those aimed at schools from disadvantaged backgrounds, can facilitate this awareness of risks. At the same time, creating a closer link between school and family, by supporting parenting sessions by school specialists, guiding parents in adopting parenting style and advising in difficult situations, can be a method that reduces the involvement of adolescents in this drug world.

The following measures may be included in this group: increasing the employment opportunities of people with low levels of education, developing the social support system for women who do not receive family help or who are victims of domestic violence, and the existence of national programs for free psychological counselling.

It aligns with the elements that may contribute to the decrease in the relapse rate and the programmes carried out in prisons with women convicted of trafficking and illicit consumption of dogs and the identification of networks to ensure the different needs of prisoners. At the same time, another factor aimed at the reintegration of women into the community may be the analysis and intervention on social networks, which supported their criminal activity in the past.

In Romania, the causes of the growth of the female population convicted of drug trafficking also include the insufficient development of social services, which is why measures of a criminal nature are applied, rather than social measures towards women who break the law. The absence of organisations to support women in difficulty and to act towards helping them adapt to society is also a sensitive matter for drug-related crimes.

As well, alternating criminal and restorative justice policies can positively influence this approach. The development of centres for drug users, depending on existing cases, can contribute to a decrease in the recidivism rate by including them in a specialised programme.

\section{Study limitations}

This article has several limitations. Because $25 \%$ of the studies had access to the abstract only, as full access required buying them for a fee, this can influence the results in a negative way. Secondly, the low number of researches on this subject has reduced the chances of highlighting several aspects leading to an understanding of this phenomenon.

In the future, a possible metaanalysis that analyzes studies in a differentiated manner, i.e. qualitative studies separate from quantitative ones, can bring significant information and a much higher level of knowledge. 


\section{Table 1}

Analyzed studies and adjacent conclusions for the keyword - women

\begin{tabular}{cllc}
\hline \multicolumn{1}{c}{ Authors, year of publication } & \multicolumn{1}{c}{ Place of study } & Study population & N \\
\hline James, Gosho, \& Wohl, (1979). & $\begin{array}{l}\text { University of Washington, } \\
\text { Seattle, Washington. }\end{array}$ & $\begin{array}{l}\text { Drug-addicted women } \\
\text { and prostitutes. }\end{array}$ & 268
\end{tabular}

Findings: For all women addicted to heroin, drug resale and prostitution were the usual means of support.

Bränström \& Andrésson, (2008). Sweden.

Women with criminal records.

Findings: The particular effects of drug policy.

Gilfus, (1993). University of Wisconsin, Incarcerated women. Madison.

Findings: Victimization of women - a factor influencing criminal activity.

Murphy, Stevens, McGrath, Wexler, Tucson, Arizona.

Abused women.

\& Reardon, (1998).

Findings: The victim profile of women involved in crime.

Stevens, Andrade, \& Ruiz, (2009). Tucson, Arizona. Tomen drug users.

Findings:Specific psychological factors involved in drug trafficking.

Haselschwerdt, Maddox, \& Hlavaty, California. Abused women. (2020).

Findings: The role of vulnerability elements.

Dodge \& Pogrebin, (2001). University of Colorado, Incarcerated women. Denver.

Findings: Collateral effects of women's incarceration. 


\section{Table 2}

Analyzed studies and adjacent conclusions for the keyword - drugs

\begin{tabular}{|c|c|c|c|}
\hline Authors, year of publication & Place of study & Study population & $\mathbf{N}$ \\
\hline Alantes, Fraile, \& Page, (2002). & $\begin{array}{l}\text { University of Valencia, } \\
\text { Spain. }\end{array}$ & $\begin{array}{l}\text { Women involved in } \\
\text { crime. }\end{array}$ & 50 \\
\hline
\end{tabular}

Findings: Risk behavior in drug trafficking.

Radosh, (2008).

Department of Womens

Women involved in drug

Studies, Western. trafficking.

Findings: The racial element in drug trafficking.

Moloney, Hunt, \& Joe-Laidler, (2015). S San Francisco, California.

Women involved in drug trafficking.

Findings: Perception of advantages and disadvantages in drug trafficking.

Hughes, Chalmers, \& Klimoski, $\quad$ National Drug and Alcohol

Women drug users.

Research Center, Australia.

Fondevila, Massa, \& Meneses-Reyes, $\quad$ Mexico city, Mexico.

Women drug users.

(2020).

Findings: Involvement of women in drug trafficking-related crimes.
Hutton, (2005).
Victoria University of Wellington, New Zealand.

Women drug users.

Findings: Drugs and risk behaviors in drug trafficking.

Flynn \& Hoffer, (2019).

Case Western Reserve

Women drug users.

University, Cleveland,

Ohio.

Findings: Social implications of drug trafficking in women

Chatwin, (2003).

England and Europen
Union.

Women involved in drug use and trafficking.

Findings: The impact of political systems on drug trafficking.

Chatwin, (2016).

Swedan and Netherlands.

Women involved in drug use and trafficking.

Findings: Impact of cultural peculiarities on drug trafficking.

Bellis et al. (2008).

European countries.

Women drug traffickers.

Findings: The connection betweeen adrenaline and drug trafficking.

Measham, (2004).

Lancaster University, UK.

Women involved in drug use and trafficking. 


\begin{tabular}{ccc}
\hline Authors, year of publication & Place of study & Study population \\
\hline
\end{tabular}

Findings: The impact of nightclubs in the phenomenon of drug trafficking.
Nucu, (2018). Romania. Women involved in drug use and trafficking.

Findings: Effects of geographical positioning in drug trafficking.

Ţical, (2019).

Romania.

Women involved in drug use and trafficking.

Findings: Economic motivation in drug trafficking.

Giommoni, Aziani, \& Berlusconi, Italy. $\quad$ Women involved in drug 50 (2017). use and trafficking.

Findings: The connection between social proximity and drug trafficking.

Mounteney, (2016). $\quad$ European countries. Women drug users.

Findings: The connection between dependent behavior and drug-trafficking.

Beaver et al. (2016).

Saudi Arabia.

Women drug users.

Findings: The role of the entourage in drug use and trafficking

Denoth, Siciliano, Iozzo, Fortunato, Italy. Teenage drug users. 33. \& Molinaro, (2011).

Findings: The role of the entourage in drug use and trafficking.

Stanciu \& Cotruş,

Romania.

Teenage drug users.

(2014).

Findings: The role of social factors in drug use and trafficking.

Baciu, (2018).

Romania.

Students.

Findings: Favorite places for drug use.

Baciu, (2019).

Romania.

Students.

Findings: The influence of the membership group on drug use.
Baciu, (2017).
Romania.
Drug users.

Findings: Informing the company about drug use 


\section{Table 3}

Analyzed studies and adjacent conclusions for the keyword - traffic

\begin{tabular}{llcl}
\hline Authors, year of publication & Place of study & Study population & N \\
\hline Johnson \& Young, (2002). & United States of America. & Abused women. & 5
\end{tabular}

Findings: The psychological implications of the victim.

$\begin{array}{lll}\text { Schemenauer, (2012). } & \text { Columbia. } & \text { Women drug traffickers. } \\ & 100\end{array}$

Findings: Confidence in one's own ability to conceal

Whitney, (2016). $\quad$ Ecuador. $\quad$ Women drug traffickers. 16

Findings: The psychological implications of the victim.

Jørgenrud et al. (2018). Norway.

Women with a history of addiction.

Findings: Risk behaviors in drug trafficking.

Ludwick, Murphy, \& Sales, (2015). $\quad$ San Francisco. $\quad$ Women drug traffickers. 160

Findings:Perception of the advantages and disadvantages of drug trafficking by women.

Calafat et al. (2009). European countries.

Women with a history of addiction.

Findings: Risk behaviors in drug trafficking.

Dotherte, Jacinto, Sales, \& Murphy, California.

Women with a history of 80 (2009). addiction.

Findings: The implications of addictive behavior.

\section{Table 4}

Analyzed studies and adicent conclusions for the keyword-addiction

\begin{tabular}{llll}
\hline \multicolumn{1}{c}{ Authors, year of publication } & \multicolumn{1}{c}{ Place of study } & Study population & N \\
\hline Grace, (2017). & England. & $\begin{array}{l}\text { Women who committed } \\
\text { drug trafficking. }\end{array}$ & 89
\end{tabular}

Findings: Addiction - survival strategy.

Robbins, Martin, \& Surratt, (2009). $\quad$ U.S.A.

Women drug users.

Findings: Intervention - measure to prevent relapse

Bui \& Morash, (2010). $\quad$ U.S.A.

Incarcerated women. 


\begin{tabular}{|c|c|c|c|}
\hline Authors, year of publication & Place of study & Study population & $\mathbf{N}$ \\
\hline \multicolumn{4}{|c|}{ Findings: Involvement of the probation service in the return process. } \\
\hline Sánchez, Fearn, \& Vaughn, (2018). & Spain. & $\begin{array}{l}\text { Women with a history of } \\
\text { addiction. }\end{array}$ & 100 \\
\hline \multicolumn{4}{|c|}{ Findings: The use of substances in prison can be a barrier to the rehabilitation objectives of these women. } \\
\hline $\begin{array}{l}\text { Wexler, Cuadrado, \& Stevens, } \\
\text { (1998). }\end{array}$ & South Florida. & $\begin{array}{l}\text { Women with a history of } \\
\text { addiction. }\end{array}$ & 83 \\
\hline \multicolumn{4}{|c|}{ Findings: The presence of psychological disorders in addictive behavior. } \\
\hline $\begin{array}{l}\text { Brownstein, Baxi, Goldstein, \& Ryan, } \\
\text { (1992). }\end{array}$ & New York. & $\begin{array}{l}\text { Women in communities } \\
\text { dealing with drug } \\
\text { trafficking. }\end{array}$ & 414 \\
\hline
\end{tabular}

\section{Table 5}

Analyzed studies and adjacent conclusions for the keyword - relapse

\begin{tabular}{|c|c|c|c|}
\hline Authors, year of publication & Place of study & Study population & $\mathbf{N}$ \\
\hline Fowler, Dinitto, \& Webb, (2005). & U.S.A. & Women drug users. & 51 \\
\hline \multicolumn{4}{|c|}{ Findings: Individual intervention in addicted behavior. } \\
\hline Olson, Stalans, \& Escobar, (2016). & $\begin{array}{l}\text { Loyola University, } \\
\text { Chicago. }\end{array}$ & Incarcerated women. & 60 \\
\hline \multicolumn{4}{|l|}{ Findings: Risk factors for relapse. } \\
\hline Bergseth, Jens, Bergeron-Vigesaa, & Chicago. & Incarcerated women. & - \\
\hline \multicolumn{4}{|l|}{ \& McDonald, (2011). } \\
\hline Holtfreter \& Morash, (2003). & U.S.A. & Incarcerated women. & 402 \\
\hline \multicolumn{4}{|c|}{ Findings: Means to stop recidivism in drug use and trafficking. } \\
\hline Dandnord \& Griffiths, (2006). & New York. & Convicted people. & - \\
\hline Dignan, (2004). & Glasgow. & Convicted people. & - \\
\hline Szabo, (2010). & Romania. & Convicted people. & - \\
\hline Braithwaite, (2002). & England. & Convicted people. & - \\
\hline \multicolumn{4}{|c|}{ Findings: The importance of the political system at the level of society. } \\
\hline Oancea \& Micle, (2015). & Romania. & Convicted people. & - \\
\hline
\end{tabular}




\begin{tabular}{lccc}
\hline \multicolumn{1}{c}{ Authors, year of publication } & Place of study & Study population & N \\
\hline Taylor, (2015). & Philadelphia, U.S.A. & Incarcerated women. & 40 \\
$\begin{array}{l}\text { Findings: Influence of the support environment by gender. } \\
\text { Micle, Oancea, Saucan, \& }\end{array}$ & Romania. & Convicted persons. & 100 \\
$\begin{array}{l}\text { Dragomirescu, (2013). } \\
\text { Findings: Inability of subjects to select important information. }\end{array}$ & \\
\hline
\end{tabular}

\section{Acknowledgements}

This study is part of the doctoral research project entitled "Dimensions of personality, emotions and cognitions in people deprived of freedom", carried out at the School of Advanced Studies of the Romanian Academy, "Constantin Rădulescu-Motru" Institute of Philosophy and Psychology, Department of Psychology, Romanian Academy, Bucharest, Romania.

\section{References}

1. Al-Abdallat, I. M., Al Ali, R., Hudaib, A. A., Salameh, G. A., Salameh, R. J., \& Idhair, A. K. (2016). The prevalence of alcohol and psychotropic drugs in fatalities of road-traffic accidents in Jordan during 2008-2014. Journal of forensic and legal medicine, 39, 130-134. https://doi.org/10.1016/j.jflm.2016.01.018

2. Alantes, C. R., Fraile, J. S., \& Page, J. B. (2002). Drug-using sex workers in the streets of valencia: Risk in context. Journal of Athonites in Substance Abuse, 1(4), 1-2. https://doi.org/10.1300/J233v01n04_01

3. Atzendorf, J., Rauschert, C., Seitz, N. N., Lochhühler, K., \& Kraus, L. (2019). The Use of Alcohol, Tobacco, Illegal Drugs and Medicines: An Estimate of Consumption and SubstanceRelated Disorders in Germany. Deutsches Ärzteblatt International, 116(35-36), 577. doi: 10.3238/arztebl.2019.0577

4. Baciu, A. (2018). Illegal drug use: Ananthropological drug phenomenon. Glasnik Anthropološkog društva Srbije [Journal of the Anthropological Society of Serbia], 53, 61-69. two:10.5937/gads53-17746, https://scindeks.ceon.rs/issue.aspx?issue=14210\&lang=en

5. Baciu, A. (2019). Aspects regarding the influence of the family and the social peer group on drug use in a lot of pupils and students from Bucharest. Anthropological Researches and Studies, 9, 153-160. http://doi.org/10.26758/9.1.15

6. Baciu, A. B. (2017). Drug Use - A Medical, Anthropological and Psychosocial Phenomenon. Aachen, Germany: Shaker Verlag.

7. Beaver, K. M., Al-Ghamdi, M. S., Kobeisy, A. N., Alqurashi, F. H., Schwartz, J. A., Connolly, E. J., \& Gajos, J. M. (2016). The effects of low self-control and dilenn peers on alcohol, tobacco, and drug use in a sample of Saudi Arabian youth. International journal of offer therapy and comparative criminology, 60(13), 1569-1587. https://doi.org/10.1177/0306624X15583670

8. Bellis, M. A., Hughes, K., Calafat, A., Juan, M., Ramon, A., Rodriguez, \& Phillips-Howard, P. (2008). Sexual use of alcohol and drugs and the associated health risks: a cross sectional study of young people in nine European cities. BMC public health, 8(1), 155. https://doi.org/10.1186/1471-2458-8-155 
9. Bergman, M. (2018). The Use of Illegal Drugs in Latin America: A Brief Introduction. In Illegal Drugs, Drug Trafficking and Violence in Latin America. Springer. https://doi.org/10.1007/9783-319-73153-7

10. Bergseth, K. J., Jens, K. R., Bergeron-Vigesaa, L., \& McDonald, T. D. (2011). Assassining the needs of women recently released from prison. Women \& Criminal Justice, 21(2), 100-122. https://doi.org/10.1080/08974454.2011.558799

11. Braithwaite, J. (2002) Restorative Justice \& Responsive Regulation. New York: Oxford University Press.

12. Bränström, R., \& Andréasson, S. (2008). Regional differences in alcohol consumption, alcohol addiction and drug use among swedish adults. Scandinavian journal of public health, 36(5), $493-$ 503. https://doi.org/10.1177/1403494807087557

13. Brownstein, H. H., Baxi, H. R. S., Goldstein, P. J., \& Ryan, P. J. (1992). The relationship of drugs, drug trafficking, and drug trafficers to homicide. Journal of Crime and Justice, 15(1), 2544. https://doi.org/10.1080/0735648X.1992.9721451

14. Bui, H. N., \& Morash, M. (2010). The impact of network relationships, prison experiences, and internal transformation on women's success after prison release. Journal of Offerer Rehabilitation, 49(1), 1-22. https://doi.org/10.1080/10509670903435381

15. Buvik, K., Bye, E. K., \& Gripenberg, J. (2019). Alcohol and drug use among staff at licensed premises in Norway. Scandinavian journal of public health, 47(4), 393-399. https://doi.org/10.1177/1403494818761417

16. Calafat, A., Blay, N., Juan, M., Adrover, D., Bellis, M. A., Hughes, K., ... \& Bohrn, K. (2009). Traffic risk behaviors at nightlife: drinking, taking drugs, driving, and use of public transport by $\begin{array}{llll}\text { young people. Traffic injury 162-169. } & \text { 162), }\end{array}$ https://doi.org/10.1080/15389580802597054

17. Carfora, A., Campobasso, C. P., Cassandro, P., Petrella, R., \& Borriello, R. (2018). Alcohol and drugs use among drivers injured in road accidents in Campania (Italy): A 8-years retrospective $\begin{array}{llll}\text { analysis. Forensic } \quad \text { science } & \text { international, }\end{array}$ https://doi.org/10.1016/j.forsciint.2018.05.003

18. Chatwin, C. (2003). Drug policy developments within the European Union. The destabilising effects of Dutch and Swedish Drug Policies. British Journal of Criminology, 43(3), 567-582. https://doi.org/10.1093/bjc/43.3.567

19. Chatwin, C. (2016). Mixed messages from Europe on drug policy reform: The houses of Sweden and the Netherlands. Journal of Drug Policy Analysis, 11(1). https://doi.org/10.1515/jdpa-2015$\underline{0009}$

20. Costa, N., Silva, R., Mendonça, M. C., Real, F. C., Vieira, D. N., \& Teixeira, H. M. (2012). Prevalence of ethanol and illegal drugs in road traffic accidents in the centre of Portugal: An eighteen-year update. Forensic science international, 216(1-3), 37-43. https://doi.org/10.1016/j.forsciint.2011.08.013

21. Dandnord, Y., \& Griffiths, C. T. (2006). Handbook on restorative justice programs. New York: United Nations Publications. Retrieved January 09, 2021 from https://www.ncjrs.gov/App/abstractdb/AbstractDBDetails.aspx?id=238708

22. Denoth, F., Siciliano, V., Iozzo, P., Fortunato, L., \& Molinaro, S. (2011). The association between overweight and illegal drug consumption in adolescents: is there an underlying influence of the sociocultural environment?. PloS one, 6(11). https://doi.org/10.1371/journal.pone.0027358 
23. Dignan, J. (2004). Understanding victims and restorative justice. McGraw-Hill Education. Glasgow: Open University Press.

24. Dodge, M., \& Pogrebin, M. R. (2001). Collateral costs of printing for women: Complications of reintegration. The Prison Journal, 81(1), 42-54. https://doi.org/10.1177/0032885501081001004

25. Dotherte, M., Jacinto, C., Sales, P., \& Murphy, S. (2009). What's in a label? Ecstasy sellers' perceptions of pill brands. Journal of psychoactive drugs, 41(1), 27-37. https://doi.org/10.1080/02791072.2009.10400672

26. Drummer, O. H., Gerostamosulos, J., Batziris, H., Chu, M., Caplehorn, J. R., Robertson, M. D., \& Swann, P. (2003). The incidence of drugs in drivers killed in Australian road traffic crashes. Forensic science international, 134(2-3), 154-162. https://doi.org/10.1016/S03790738(03)00134-8

27. Faupel, C. E. (1987). Heroin use and killer careers. Qualitative Sociology, 10(2), 115-131. https://doi.org/10.1007/BF00988524

28. Faupel, C. E. (2010). Heroin use, street crime, and the "main hustle": Implications for the validity of official crime data. Deviant Behavior, $\quad 7(1), \quad 31-45$. https://doi.org/10.1080/01639625.1986.9967693

29. Flynn, K. C., \& Hoffer, L. D. (2019). Transitioning illegally drug preferences and emerging user identities in Ohio: the proliferation of methamphetamine use among African Americans. Journal of ethinity in substance abuse, 18(1), 67-88. https://doi.org/10.1080/15332640.2017.1325809

30. Fondevila, G., Massa, R., \& Meneses-Reyes, R. (2020). War on Drugs, War on Women: Visualizing Female Homicide in Mexico. Women \& Criminal Justice, 30(2), 147-154. https://doi.org/10.1080/08974454.2019.1653812

31. Fowler, D. N., Dinitto, D. M., \& Webb, D. K. (2005). Racial/Ethnic differences in dual diagnosed Anglo and ethnic minority women receiving chemical addiction treatment. Journal of Athonites in Substance Abuse, 3(3), 1-16. https://doi.org/10.1300/J233v03n03_01

32. Gilfus, M. E. (1993). From victims to survivors to offerers: Women's routes of entry and immersion into street crime. Women \& Criminal Justice, 4(1), 63-89. https://doi.org/10.1300/J012v04n01_04

33. Giommoni, L., Aziani, A., \& Berlusconi, G. (2017). How do Ilicit drugs move across countries? A network analysis of the heroin supply to Europe. Journal of Drug Issues, 47(2), 217-240. https://doi.org/10.1177/0022042616682426

34. Grace, S. (2017). Effective interventions for drug using women offerers: a narrative literature review. Journal of Substance Use, 664-671. https://doi.org/10.1080/14659891.2017.1278624

35. Haselschwerdt, M. L., Maddox, L., \& Hlavaty, K. (2020). Young adult women's perceptions of their maritally violent fathers. Family relations, 69(2), 335-350. https://doi.org/10.1080/14659891.2017.1278624

36. Holtfreter, K., \& Morash, M. (2003). The needs of women offerers. Women \& Criminal Justice, 14(2-3), 137-160. https://doi.org/10.1300/J012v14n02_07

37. Hughes, C. E., Chalmers, J., \& Klimoski, M. (2018). Assassining concordance between trends in high-level drug trafficking and other serious and organized crimes in Australia, 2005-2006 to 2014-2015. Drugs: Education, Prevention and Policy, 25(3), 217-233. https://doi.org/10.1080/09687637.2017.1358357

38. Hutton, F. (2005). Risky business: Gender, drug dealing and risk. Addiction Research \& Theory, 13(6), 545-554. https://doi.org/10.1080/16066350500338237 
39. Iwamoto, D., Liu, W. M., \& McCoy, T. E. (2011). An exploratory model of substance use among Asian American women: The role of depression, coping, peer use and Asian values. Journal of ethinity in substance abuse, 10(4), 295-315. https://doi.org/10.1080/15332640.2011.623494

40. James, J., Gosho, C., \& Wohl, R. W. (1979). The relationship between female criminals and drug use. International Journal of the Addictions, 14(2), 215-229. https://doi.org/10.3109/10826087909060367

41. Johnson, H. D., \& Young, D. S. (2002). Addiction, abuse, and family relationships: Childhood experiences of five incarcerated African American women. Journal of Athonites in Substance Abuse, 1(4), 29-47. https://doi.org/10.1300/J233v01n04_02

42. Jørgenrud, B., Bogstrand, S. T., Furuhaugen, H., Jamt, R. E., Vendenes, V., \& Gjerde, H. (2018). Association between speeding and use of alcohol and medicinal drugs and involvement in road traffic crashes among motor vehicle drivers. Traffic injury prevention, 19(8), 779-785. https://doi.org/10.1080/15389588.2018.1518577

43. Kartashev, V., Döring, M., Nieto, L., Colette, E., Kaiser, R., Sierra, S., ... \& Nevens, F. (2016). New findings in HCV genotype distribution in selected West European, Russian and Israeli regions. Journal of Clinical Virology, 81, 82-89. https://doi.org/10.1016/j.jcv.2016.05.010

44. Kensy, J., Stengal, C., Nouvier, M., \& Birgin, R. (2012). Drug policy and women: Addressing the negative consequences of harmful drug control. International Drug Policy Consortium, 3(2), 323-334. http://dx.doi.org/10.2139/ssrn.2186004

45. Ludwick, M. D., Murphy, S., \& Sales, P. (2015). Savvy sellers: dealing drugs, doing gender, and $\begin{array}{llll}\text { doing difference. Substance } \quad \text { use } \quad \text { misuse, } & \text { 50(6), }\end{array}$ https://doi.org/10.3109/10826084.2015.978640

46. Marsh, W. (2016). Drug mules: women in the international cocaine trade. Journal of Criminal Justice Education, 28(1), 159-153. https://doi.org/10.1080/10511253.2016.1161885

47. Measham, F. (2004). Play space: Historical and socio-cultural reflections on drugs, licensed leisure locations, commercialisation and control. International Journal of Drug Policy, 15(5-6), 337-345. https://doi.org/10.1016/j.drugpo.2004.08.002

48. Micle M. I., Oancea G., Saucan D. Ş., \& Dragomirescu S. (2013). Factori asociaţi recidivei în cazul persoanelor condamnate. Philosophical-Psychological Research, 1, 119 - 130. [Factors associated with recidivism in the case of convicted persons]. Retrieved January 09, 2021 from http://www.research.institutuldephilosophy.ro/e107_files/downloads

/Archive\%20C.F.P./Research\%20filologicopsychological\%20anul\%20V\%20nr.\%201\%20[201 3].pdf

49. Moloney, M., Hunt, G., \& Joe-Laidler, K. (2015). Drug sales, gender, and risk: Notions of risk from the perspective of gang-involved young adults. Substance use \& misuse, 50(6), 721-732. https://doi.org/10.3109/10826084.2015.978642

50. Montanari, L., Guarita, B., Mounteney, J., Zipfel, N., \& Simon, R. (2017). Cannabis use among people entering drug treatment in Europe: a growing phenomenon?. European Addiction Research, 23(3), 113-121. Retrieved November 23, 2020 from https://www.karger.com/Article/PDF/475810

51. Mounteney, J., Griffiths, P., Sedefov, R., Noor, A., Vicente, J., \& Simon, R. (2016). The drug situation in Europe: an overview of data available on illegal drugs and new psychoactive substances from European monitoring in 2015. Addiction, 111(1), 34-48. https://doi.org/10.1111/add.13056 
52. Murphy, B. S., Stevens, S. J., McGrath, R. A., Wexler, H. K., \& Reardon, D. (1998). Women and violence: A different look. Drugs \& Society, 13(1-2), 131-144. https://doi.org/10.1300/J023v13n01_08

53. Nucu, M. (2018). Brigade for Combating Organized Crime Constanta, Romania International institutions trained in preventing and combating illicit drug trafficking. Cross-border and transnational crime, 13(2) 148-153. Retrieved November 11, 2020 from https://ibn.idsi.md/ro/vizualizare_articol/92023

54. Oancea, G., Micle, M. I. (2015). New approaches in criminal law on psychosocial rehabilitation of offenders, Journal of Psychology, 61(4), 308-316. Retrieved January 09, 2021 from http://www.revistadepsihologie.ipsihologie.ro/images/revista _de_psihologie/2015_4/Rev_Psihol_4_2015.pdf\#page=70

55. Olson, D. E., Stalans, L. J., \& Escobar, G. (2016). Comparing male and female prison releases across risks and postprison recidivism. Women \& Criminal Justice, 26(2), 122-144. doi:10.1080/08974454.2015.1083930

56. Radosh, P. F. (2008). War on drugs: Gender and race inequities in crime control $\begin{array}{llll}\text { strategies. Criminal } \quad \text { Justice } & \text { Studies, } & \text { 167-178. }\end{array}$ https://doi.org/10.1080/14786010802159830

57. Ritchie, A. J. (2017). Invisible no more: Police violence against Black women and women of color. Boston: Beacon press. https://doi.org/10.1080/10439463.2019.1650746

58. Robbins, C. A., Martin, S. S., \& Surratt, H. L. (2009). Substance abuse treatment, anticipated maternal roles, and reentry successes of drug-involved women prisoners. Crime \& Delinquency, 55(3), 388-411. https://doi.org/10.1177/0011128707306688

59. Sánchez, F. C., Fearn, N., \& Vaughn, M. G. (2018). Prevalence and correlations of in-prison substance use among incarcerated women in Spain. Journal of ethinity in substance abuse, 17(3), 356-374. https://doi.org/10.1080/15332640.2016.1255579

60. Schemenauer, E. (2012). Victims and vamps, madonnas and whores: the construction of female drug couriers and the practices of the US Security State. International Feminist Journal of Politics, 14(1), 83-102. https://doi.org/10.1080/14616742.2011.631277

61. Stanciu, C., \& Cotruş, A. (2014). Psychological and social factors involved in drug use in adolescents. Journal of Neurology and Psychiatry of The Child and Adolescent in RomaniaMarch, 17(1), 21. Retrieved November 14, 2020 from http://snpcar.ro/wpcontent/uploads/2018/08/pdf52.pdf

62. Stevens, S. J., Andrade, R. A., \& Ruiz, B. S. (2009). Women and substance abuse: Gender, age, and cultural considerations. Journal of Athonites in Substance Abuse, 8(3), 341-358. https://doi.org/10.1080/15332640903110542

63. Szabo, A. (2010). De la justiţia restaurativă la practicile restaurative: aplicabilitate în domeniul asistenţei sociale. Social Assistance Magazine, 1, 125-147. [From restorative justice to restorative practices: applicability in the field of social assistance] Retrieved December 12, 2020 from https://www.ceeol.com/search/article-detail?id=64336

64. Taylor, C. J. (2015). Gendered paths to recidivism: Differential effects of family support by $\begin{array}{lllll}\text { gender. Women } \quad \& \quad \text { Criminal } & \text { Justice, } & \text { 25(3), }\end{array}$ https://doi.org/10.1080/08974454.2014.989305

65. Tical, G. (2019). Trends of Cocaine Trafficking at the Level of Romania. Journal of the Academy of Sciences of National Security, 13(1). Retrieved November 28, 2020 from https://papers.ssrn.com/sol3/papers.cfm?abstract_id=3430293 
66. Van Ness, D., Morris, A., \& Maxwell, G. (2001). Introducing restorative justice. Restorative justice for juveniles: Conferencing, mediation and circles. Oxford: Hart Publishing.

67. Walker, E. R., Pratt, L. A., Schoenborn, C. A., \& Druss, B. G. (2017). Excess mortality among people who report lifetime use of illegal drugs in the United States: A 20-year follow-up of a nationally representative survey. Drug and alcohol addiction, 171, 31-38. https://doi.org/10.1016/j.drugalcdep.2016.11.026

68. Wexler, H. K., Cuadrado, M., \& Stevens, S. J. (1998). Residential treatment for women: Behavioral and psychological outcomes. Drugs \& Society, 13(1-2), 213-233. https://doi.org/10.1300/J023v13n01_13

69. ***National Anti-drug Agency (2019). Raport naţional privind situaţia drogurilor. [National drug situation report]. Retrieved November 07, 2020 from http://ana.gov.ro/raportul-nationalprivind-situatia-drogurilor-2019/ 